\title{
ПРОБЛЕМАТИКА ТА ПЕРСПЕКТИВИ ФІНАНСОВОГО МОНІТОРИНГУ У СФЕРІ ОБІГУ КРИПТОВАЛЮТ
}

\author{
КОВРИГА Микола Миколайович - аспірант кафедри публічно-правових \\ дисциплін Київського міжнародного університету
}

DOI:10.32782/EP.2020.1.26

УДК 347.73

В представленной статье приведенъ исследования проблематики бинансового мониторинга в сбере обращения криптовалют. Особое внимание уделено исследованию проблем идентификации, верификаиии и изучения участников бинансовъх операций с криптовалютами.

Проанализированъ основнъие аспекть анонимности криптовалют, современнъие разработки в сбере обработки даннъих криптовалютных транзакиий. В ходе исследования бъли рассмотренъ криптовалюты по возможности их деанонимизащии. Так, существуюшие на сегодня криптовалють можно разделить на криптовалютьл, информацию о транзакииях которьхх можно проанализировать, классифицировать, систематизировать и криптовалюты с повышенной анонимностью.

В ходе исследования также проанализированъ последние мировые тендениии по определению правового статуса криптовалют. Проведен анализ последних изменений отечественного законодательства в данной сфере. Сделанъ въиодь иелесообразности выбранного направления регулирования, поскольку указанные изменения основъиваются именно на мировом опьтте, а также рекомендациях и экспертизе международнъгх организачий.

Ключевъе слова: криптовалюта, бинансовъй мониторинг, Bitcoin, CryptoNote, анонимность транзакиий.

\section{Постановка проблеми}

3 розвитком сучасних технологій з'являється все більше можливостей для відмивання грошей, отриманих незаконним шляхом, шахрайських схем, фінансуванню протизаконної діяльності. У таких умовах поява криптовалют стала суттєвим викликом наявній системі фінансового моніторингу. Анонімність криптовалютних транзакцій зумовила необхідність пошуку та розробки нових способів контролю за обігом активів, для забезпечення належної протидії незаконній діяльності.

3 огляду на потребу актуального регулювання даної сфери, доцільно дослідити проблематику фінансового моніторингу криптовалютного ринку, в тому числі можливість і перспективи ідентифікації та верифікації учасників фінансових операцій з криптовалютами.

Незважаючи на суттєвий інтерес як практичний, так і теоретичний, дане питання ще $є$ недостатньо дослідженим.

\section{Аналіз дослідження}

Інноваційність, широкий спектр застосування, потенціал такого явища як криптовалюти, зумовили зростання наукових зацікавлень як вітчизняних, так i зарубіжних учених. Даному питанню приділяли увагу в тому числі: А. Колдовський,Є.Н. Аобачова, В.Г., А. Грінспен, Б. Бернанк, , Ф. Журавко, А. Т. Проценко, С. Б. Родіонова, іР. Шульц, Д. Ален, М. Спіфанов, М. Абрамович, Дж. Потс, Д. С. Вахрушев та ін. Проте, існуюча проблематика правового регулювання криптовалют, проблематика фінансового моніторингу крипто- 
валютного ринку потребують подальшого дослідження та теоретичного аналізу.

\section{Формулювання цілей дослідження}

Метою статті є дослідження проблематики, оцінка потенціалу та перспектив фінансового моніторингу у сфері обігу криптовалют.

\section{Виклад основного матеріалу}

Сучасні технології створили безліч можливостей для фінансування нелегальної діяльності, шахрайства, відмивання коштів, отриманих незаконним шляхом тощо. За таких умов стає дедалі складніше здійснювати фінансовий моніторинг. Щоб відповідати на сучасні виклики, наявна система фінансового моніторингу повинна враховувати виникнення нових ризиків, активно використовувати новітні механізми та технології, щоб ефективно здійснювати запобігання та протидію легалізації (відмиванню) доходів, одержаних злочинним шляхом, фінансуванню тероризму тощо.

Дослідження проблематики фінансового моніторингу треба починати 3 визначення даного поняття. За авторським тлумаченням А. А. Булаєва, фінансовий моніторинг - це комплекс фінансово-правових заходів, спрямованих на запобігання легалізації (відмиванню) доходів, одержаних злочинним шляхом, і фінансуванню тероризму, а також проникнення таких доходів у фінансову систему країни. Будучи вихідною ланкою системи протидії легалізації злочинних доходів і фінансуванню тероризму, фінансовий моніторинг водночас виступає елементом забезпечення не тільки економічної і фінансової, а й національної безпеки держави [1, с. 10-11].

За Словником фінансово-правових термінів (за заг. ред. д.ю.н., проф. А.К. Воронової) фінансовий моніторинг (лат. моnitor - той, хто попереджає, радник, консультант) - це механізм здійснення постійного спостереження за фінансовою діяльністю, насамперед кредитних установ, а також оцінка, аналіз і прогноз імовірності здійснення незаконних фінансових операцій. Метою фінансового моніторингу є запобігання здійсненню та своєчасне виявлення фінансових операцій, пов'язаних із легалізацією (відмиванням) доходів, одержаних злочинним шляхом [2, с. 515].

У свою чергу, відповідно до Закону України «Про запобігання та протидію легалізації (відмиванню) доходів, одержаних злочинним шляхом, фінансуванню тероризму та фінансуванню розповсюдження зброї масового знищення» в редакції від 24.11.2018 р., фінансовий моніторинг це сукупність заходів, які здійснюються суб'єктами фінансового моніторингу у сфері запобігання та протидії легалізації (відмиванню) доходів, одержаних злочинним шляхом, фінансуванню тероризму та $\phi і-$ нансуванню розповсюдження зброї масового знищення, що включають проведення державного фінансового моніторингу та первинного фінансового моніторингу [3].

Аналізуючи зазначені визначення фінансового моніторингу, можна узагальнити, що фінансовий моніторинг - це система заходів, націлена на здійснення спостереження за фінансовими операціями, ціллю чого є виявлення сумнівних транзакцій та ідентифікації даних учасників таких транзакцій, 3 метою ініціювання додаткових процедур (перевірка, уточнення, зупинка, затримання тощо).

Ключовим завданням та етапом первинного фінансового моніторингу є ідентифікація, верифікація та вивчення клієнта (учасника фінансової операції).

Одним із основних викликів для фінансового моніторингу стали розвиток та розповсюдження операцій 3 криптовалютами, адже за своєю технологічною суттю криптовалюти вважаються досить анонімним способом перерахування коштів, що суттєво ускладнює процедуру ідентифікації учасника фінансової операції.

У своєму звіті від червня 2019 року Свропейська Комісія, серед іншого, виділила анонімність фінансових транзакцій та проблему виявлення інформації про бенефіціарну власність активів, як одні із основних ризиків у сфері запобігання та протидії легалізації (відмивання) доходів, одержаних злочинним шляхом [4, с. 6].

У свою чергу, питання анонімності криптовалют досить неоднозначне. Так, 


\section{Банківське та фінансове право}

більшість із них, такі як Bitcoin (BTC), Litecoin (LTC), Ethereum (ETH), Bitcoin Cash (BCH), Tether (USDT) $є$ криптовалютами відкритого (публічного) реєстру (блокчейн). Це означає що у вільному доступі є інформація про будь-яку транзакцію, здійснену в межах мережі відповідної криптовалюти. Так, для прикладу на порталі блокчейн-гаманця Blockchain.com [5] можна відслідкувати будь-яку транзакцію, здійснену в мережі Bitcoin в будь-який момент існування даної мережі. Із доступної інформації відомі такі дані, як номер (ідентифікатор) транзакції, адреса гаманця відправника, адреса гаманця отримувача, дата та час здійснення транзакції, сума в Bitcoin, вартість в еквіваленті фіатної валюти (наприклад, долар США) на момент здійснення транзакції. За вказаною інформацією цілком можливо відслідкувати перерахування коштів 3 певних гаманців, єдиною суттєвою складністю є лише те, що зареєструвати гаманець для криптовалют $\epsilon$ простою та анонімною процедурою, і як наслідок при можливості відслідкувати історію транзакцій по певному гаманцю, на початкових етапах користування, в абсолютній більшості випадків, досить складно 3'ясувати, кому саме такий гаманець належить.

Однак 3 розвитком сучасних технологій аналіз та відслідковування даних про обіг криптовалют став цілком можливим. Певні технологічні компанії, такі як CipherTrace (https://ciphertrace.com/), Chainalysis (https://www.chainalysis.com/) i Elliptic (https://www.elliptic.co/), активно розвивають напрямок аналізу даних у сфері обігу криптовалют. На сьогодні програмні рішення таких компаній здатні запропонувати досить широкий спектр можливостей.

Криміналістична компанія Chainalysis y змозі відслідковувати більше двадцяти різних маркерів, відносно токенів стандарту ERC20, які можуть взаємодіяти з іншими токенами в мережі блокчейну Ethereum. Представники Chainalysis заявляють, що на основі їхніх розробок можливо відстежувати інформацію про транзакції ключових, за капіталізацією, криптовалют, що, у свою чергу, забезпечує «видимість у $87 \%$ світового обсягу торгів криптовалютами» [6].

Співзасновник Chainalysis Джонатан левін (англ. Jonathan Levin) заявив, що державні регулятори та слідчі органи були зацікавлені у моніторингу цих маркерів, оскільки їх почали використовувати в незаконній та шахрайській діяльності [6]. Так, наприклад, у 2019 році біржа Binance (https://www.binance.com/ua) стала жертвою хакерської атаки, в результаті якої було викрадено криптовалют на 40,5 мільйонів доларів США, у 2016 році з криптовалютної біржі Bitfinex (https://www.bitfinex. com/?locale $=\mathrm{ru})$ було викрадено криптовалюти на 65 мільйонів доларів США [7].

Chainalysis планують забезпечити відслідковування загалом 39 токенів стандарту ERC20 та дев'яти інших криптовалют, що дасть змогу покрити моніторингом більш ніж 90\% ринку криптовалют [6].

Постачальник аналітичних рішень CipherTrace також посилила моніторинг і тепер відстежує 700 різних криптовалютних токенів. Під моніторингом знаходиться велика кількість цифрових активів, таких, наприклад, як Bitcoin (BTC), Litecoin (LTC), Ethereum (ETH), Bitcoin Cash (BCH), Tether (USDT) та токени типу ERC20 [6].

За даними Ciphertrace, їхня платформа спроможна обробити 522 мільйони точок даних, таких як тип рахунку, власники рахунків, типи договорів, власники контрактів та інші метадані. Для деанонімізації транзакцій з криптовалютами, компанії використовують різні методи та інструменти, такі, наприклад, як аналіз API (інтерфейс прикладного програмування), інтерактивну візуалізацію, бази даних графіків, розпізнавання шаблонів тощо [6].

Послугами 3 виявлення незаконних дій 3 операціями вже користуються приватні замовники та державні структури, для прикладу в Сполучених штатах Америки - це Служба внутрішніх доходів США (IRS), Управління боротьби з наркотиками (DEA), Служба міграції та митного забезпечення США (ICE), Федеральне бюро розслідувань (FВI) та інші агентства [6]. 
Однак, незважаючи на суттєвий прогрес у сфері моніторингу ринку криптовалют, існує тип криптовалют, побудованих на протоколі прикладного рівня CryptoNote, який, у свою чергу, забезпечує більшу анонімність відносно «класичних» криптовалют, таких як Bitcoin. Анонімність таких криптовалют реалізована за допомогою технології кільцевої підпису, яка дозволяе підписати транзакцію від імені групи. Підпис говорить тільки про те, що транзакція здійснена кимось 3 групи, але всі учасники групи не відрізняються один від одного. Ніхто не в змозі зробити один і той же платіж двічі. Використовується змінений протокол обміну Діффі-Хеллмана, що зіставляє унікальні адреси з відкритим ключем [8]. До таких криптовалют належать Bytecoin, Monero, DarkNote, DASH та перша українська криптовалюта KARBO (Карбованець).

При цьому анонімність криптовалют, побудованих на протоколі CryptoNote, також не $є$ абсолютною. За певних умов, та якщо зловмиснику належить достатній відсоток мережі певної криптовалюти, можуть виникнути ланцюжкові реакції відстеження транзакцій (та інших даних) всієї мережі [9].

3 огляду на те, що об'єми операцій 3 криптовалютами збільшуються, а сучасні можливості відслідковування даних таких операцій все ще є надто обмеженими, для належного регулювання та фінансового моніторингу обігу криптовалют доцільно використовувати регулятивний метод щодо суб'єктів, які адмініструють даний ринок, криптовалютні біржі, обмінні платформи, підприємці, які взаємодіють 3 криптовалютними транзакціями.

Такий підхід використовують міжнародні інституції у сфері фінансового моніторингу. Для прикладу, Міжнародна група з протидії відмиванню брудних грошей (FATF) (англ. Financial Action Task Force on Money Laundering, фp. Groupe d'action financière; GAFI) у жовтні 2018 року надала рекомендації, згідно з якими вимоги фінансового моніторингу застосовуються й до фінансової діяльності, що включає «віртуальні активи» (в тому числі криптовалю- ти) та «постачальників послуг з віртуальними активами». Згідно з наданими рекомендаціями постачальники послуг 3 віртуальними активами повинні підпадати під регулювання законодавства про запобігання та протидію відмиванню коштів та фінансуванню тероризму, отримувати ліцензію, бути об'єктом системи моніторингу та нагляду, мати той самий набір зобов'язань, що і фінансові установи [10, с.4].

Україна у своїй діяльності використовує подібний підхід щодо фінансового моніторингу обігу криптовалют. Так, у статтю 6 Закону України «Про запобігання та протидію легалізації (відмиванню) доходів, одержаних злочинним шляхом, фінансуванню тероризму та фінансуванню розповсюдження зброї масового знищення» № 361-IX в редакції від 06.12.2019 р., яка набуває чинності 28.04.2020 р., до переліку суб'єктів первинного фінансового моніторингу було додано постачальників послуг, пов'язаних 3 обігом віртуальних активів [11].

Даним законом також передбачено, що операції з віртуальними активами, еквівалент яких перевищує тридцять тисяч гривень, підлягає фінансовому моніторингу. Зокрема, постачальники послуг, пов'язаних 3 обігом віртуальних активів (наприклад, криптовалютна біржа) зобов'язані проводити, в тому числі, процедуру ідентифікації та верифікації платника (ініціатора переказу) та отримувача переказу [11].

Також до статті 46 Закону України «Про запобігання корупції» № 1700-VII від 14.10.2014 р., в редакції від 02.10.2019 р., було внесено зміни, якими до об'єктів, які підлягають декларуванню, було додано нематеріальні активи, що належать суб'єкту декларування або членам його сім'ї, у тому числі об'єкти інтелектуальної власності, що можуть бути оцінені в грошовому еквіваленті криптовалюти. До відомостей щодо нематеріальних активів включаються дані про вид та характеристики таких активів, вартість активів на момент виникнення права власності, а також про дату виникнення права на них [12]. 


\section{Банківське та фінансове право}

\section{Висновки}

Поява та активний розвиток криптовалют зумовили необхідність перегляду підходів до здійснення фінансового моніторингу в сучасних умовах. Ключовою проблемою фінансового моніторингу у сфері обігу криптовалют $\epsilon$ анонімність криптовалютних транзакцій. Незважаючи на це, така анонімність не $\varepsilon$ абсолютною, адже більшість криптовалют $є$ криптовалютами «відкритого» типу, тобто використовують технологію публічного реєстру, де відображаються всі транзакції здійснені колинебудь у межах певної мережі. Хоча наявні у публічному доступі дані про криптовалютні транзакції, в основному, існують у зашифрованому вигляді, існують способи систематизації та аналізу інформації про такі операції. Саме тому сьогодні активно розвиваються компанії, бізнес-моделі яких побудовані на наданні послуг з систематизації та моніторингу даних на ринку криптовалют.

Крім того, у сфері фінансового моніторингу вже $\varepsilon$ напрацьовані принципи регулювання, які дають можливість забезпечити певний контроль та аналіз криптовалютних операцій. Україна не стала виключенням і також почала впроваджувати зміни у законодавство для врегулювання даної проблематики. Позитивним аспектом можна виділити те, що даний процес є досить системним, а вказані зміни до законодавства враховують зарубіжний досвід та рекомендації міжнародних експертів.

\section{Аітература}

1. Булаев А. А. Финансово-правовые аспекты противодействия легализации (отмыванию) доходов, полученных преступным путем, и финансированию терроризма : автореф. дис. на здобуття наук. ступеня канд. юр. наук : спец. 12.00.14 «административное право»/ Булаев А. А. - M., 2010. - 26 с.

2. Словник фінансово-правових термінів / [за заг. ред. д.ю.н., проф. А.К. Воронової]. - 2-ге вид., переробл. і доповн. - К.: Алерта, 2011. - 558 с.

3. Закон України «Про запобігання та протидію легалізації (відмиванню) дохо- дів, одержаних злочинним шляхом, фінансуванню тероризму та фінансуванню розповсюдження зброї масового знищення» № 1702-VII від 14.10.2014 p. URL: https:// zakon.rada.gov.ua/laws/show/1702-18\#Text (дата звернення: 10.01.2020 р.)

4. Report from the commission to the european parliament and the council on the assessment of the risk of money laundering and terrorist financing affecting the internal market and relating to cross-border activities. URL: https://ec.europa.eu/info/sites/info/ files/supranational_risk_assessment_of_the_ money_laundering_and_terrorist_financing_ risks_affecting_the_union.pdf (дата звернення: 10.01 .2020 р.)

5. Електронний ресурс. URL: https:// www.blockchain.com/btc/unconfirmedtransactions (дата звернення: 10.01.2020р.)

6. Jamie Redman. $80 \%$ of Crypto Trade Volume Tracked by Blockchain Surveillance. URL: https://news.bitcoin.com/80-of-cryptotrade-volume-tracked-by-blockchainsurveillance/ (дата звернення: 10.01.2020 p.)

7. Самые громкие взломы криптобирж. URL: https://kuna.io/blog/exchangeshacking/\# (дата звернення: 10.01.2020р.)

8. CryptoNote - убийца Bitcoin? URL: https://bits.media/cryptonote/ (дата звернення: 10.01.2020 р.)

9. Surae Noether, Sarang Noether and Adam Mackenzie. A Note on Chain Reactions in Traceability in CryptoNote 2.0. URL: https://lab.getmonero.org/pubs/MRL-0001. pdf (дата звернення: 10.01.2020р.)

10. Керівництво щодо Ризик-Орієнтованого Підходу до Віртуальних Активів та Постачальників Послуг з Переказу Віртуальних Активів, FATF, Париж, 2019. URL: https://ru.scribd.com/document/ 414096782/ Embargo-Virtual-Asset-Guidance\# from embed (дата звернення: 10.01.2020р.)

11. Закон України «Про запобігання та протидію легалізації (відмиванню) доходів, одержаних злочинним шляхом, фінансуванню тероризму та фінансуванню розповсюдження зброї масового знищення» № 361-IX від 06.12.2019 p. URL: https:// zakon.rada.gov.ua/laws/show/361-20\#Text (дата звернення: 10.01.2020р.) 


$$
\begin{aligned}
& \text { д } \\
& p \\
& n
\end{aligned}
$$

АНОТАЦІЯ

У представленій статті наведено дослідження проблематики фінансового моніторингу у сфері обігу криптовалют. Окрему увагу приділено дослідженню проблем ідентибікаціӥ, верифікациї та вивчення учасників бінансових операчій з криптовалютами.

Проаналізовано основні аспекти анонімності криптовалют, сучасні розробки у сбері обробки даних криптовалютних транзакиій. У ході дослідження було розглянуто криптовалюти за можливістю їх деанонімізаиї. Так, наявні на съогодні криптовалюти можна розділити на криптовалюти, інформащію про транзакиій яких можна проаналізувати, класифікувати, систематизувати на криптовалюти з підвищеною анонімністю.

у ході дослідження також проаналізовано останні світові тендениї щодо визначення правового статусу криптовалют та проведено аналіз останніх змін вітчизняного законодавства в даній сфері. Зроблено висновки дочільності обраного напрямку регулювання, оскільки вказані зміни базуються саме на світовому досвіді, а також рекомендачіях та експертизі міжнародних організачій.

Ключові слова: криптовалюта, бінансовий моніторинг, Bitcoin, CryptoNote, анонімність транзакиій.

12. Закон України «Про запобігання корупції» № 1700-VII від 14.10.2014 p. URL: https://zakon.rada.gov.ua/laws/show/170018\#top (дата звернення: 10.01.2020р.)

\section{SUMMARY}

The article presents research on the problems of financial monitoring in the sphere of cryptocurrency circulation. Special attention is paid to the study of problems of identification, verification and study of participants in financial transactions with cryptocurrencies.

The main aspects of cryptocurrency anonymity and current developments in the processing of cryptocurrency transaction data were analyzed. In the course of the study, cryptocurrencies were considered for possible deanonymization. So, the existing cryptocurrencies can be divided into cryptocurrencies, information about transactions that can be analyzed, classified, systematized, and cryptocurrencies with increased anonymity. The first type includes most cryptocurrencies on the market, including Bitcoin (BTC), Litecoin (LTC), Ethereum (ETH), Bitcoin Cash (BCH), Tether (USDT). In turn, cryptocurrencies with enhanced anonymity built on the Cryptonote Protocol include bytecoin, Monero, DarkNote, DASH and the first Ukrainian cryptocurrency KARBO (Karbowanec).

This article examines the achievements of such global companies as CipherTrace, Chainalysis and Elliptic, which are actively developing the direction of data analysis in the field of cryptocurrency circulation. Their software solutions are able to offer a fairly wide range of monitoring capabilities for almost $87 \%$ of the cryptocurrency market, in order to systematize and process information about the account type of account holders, types of contracts, contract holders, and so on.

The study also analyzes the latest trends in the global approach to determining the legal status of cryptocurrencies. For example, Financial Action Task Force on Money Laundering (FATF) recommends that cryptocurrencies should be considered as «virtual assets». At the same time, financial transactions with such virtual assets, according to experts, should be subject to regulation and financial monitoring, as well as any other financial transactions. Financial monitoring of cryptocurrency circulation, first of all, should be carried out by controlling «service providers with virtual assets». According to experts, such service providers with virtual assets should be subject to the regulation of legislation on preventing and combating money laundering and terrorist financing, receive a license, be subject to a monitoring and supervision system, and have the same set of obligations as financial institutions.

The article also analyzes the latest changes in domestic legislation in this area. Conclusions are drawn about the appropriateness of the chosen direction of regulation, since these changes are based on world experience, as well as recommendations and expertise of organizations such as FATF.

Keywords: cryptocurrency, financial monitoring, Bitcoin, CryptoNote, transaction anonymity. 